\title{
Crítica textual e transparência dos traços linguísticos: as vírgulas de um manuscrito setecentista
}

\section{Textual criticism and transparency of linguistic traits: the commas of an 18th century manuscript}

\author{
Marcelo Módolo* \\ Maria de Fátima Nunes Madeira**
}

\section{RESUMO}

Este artigo pretende verificar o funcionamento do emprego das vírgulas no texto da carta régia de 1755 , documento que constituirá o primeiro corpus da pesquisa, e relacionar esse uso com dois tratados ortográficos, que formarão o segundo corpus: Regras da lingua portuguesa, espelho da lingua latina, de Argote (1725); e Orthographia, ou arte de escrever; e pronunciar com acerto a língua portuguesa, de Madureira Feijó (1734). Todavia, por se tratar de um manuscrito, primeiramente destacaremos suas propriedades filológicas, tarefa imprescindível para se endossar o documento como autêntico e original, e assim disponibilizá-lo como fonte segura para pesquisas das diversas áreas do conhecimento.

Palavras-chave: filologia portuguesa, fonte documental, emprego de vírgulas.

Recebido em 24 de julho de 2020.

Aceito em 22 de dezembro de 2020.

DOI: http://dx.doi.org/10.18364/rc.2021n61.474

*Universidade de São Paulo, São Paulo, CNPq, modolo@usp.br, https://orcid.org/0000-0001-5808-9368

**Universidade de São Paulo, fatima.madeira@usp.br, https://orcid.org/0000-0001-6141-0714

Confluência. Rio de Janeiro: Liceu Literário Português, n. 61, p. 8-47, jul.-dez. 2021 


\section{ABSTRACT}

This article intends to verify how commas were used in the text of the 1755's royal letter, a document that will constitute the first corpus of the research, and then to relate this use to two orthographic treatises, which will form the second corpus: Argote's rules of the Portuguese language, mirror of the Latin language (1725); and Madureira Feijó's orthographia, or art of writing; and to pronounce the Portuguese language correctly (1734). However, because it is a manuscript, we will first highlight its philological properties, an indispensable task to endorse the document as authentic and original, and thus make it available as a safe source of research for the various areas of knowledge.

Keywords: Portuguese philology, documental source, usage of commas.

\section{Introdução}

Spina (2003, p. 34) ensina que quando trabalhamos com documentação manuscrita, devemos ter também um comportamento crítico perante os mesmos documentos, analisando seus aspectos externos, ou seja, sua autenticidade e originalidade, como também os seus aspectos internos, isto é, devemos situarnos na época do texto, impregnarmo-nos do espírito dessa época e do meio em que o mesmo foi escrito, para o compreendermos na sua profundidade. $\mathrm{Ou}$ seja, pretendemos uma leitura filológica, nos dizeres de SAID (2004).

Essa análise das características internas e externas do manuscrito constituirá a primeira parte deste estudo. O contexto da carta régia de D. José I - o terremoto ocorrido em Lisboa, no dia $1^{\circ}$. de novembro de 1755 - distingue o manuscrito como possível fonte de informações históricas. Entretanto, para garantir o seu estatuto de documento autêntico, que o classifica como bem cultural e patrimonial do século XVIII, são necessárias aplicações metodológicas de ciências afins à Filologia, como a paleografia, a codicologia e a diplomática, cujos resultados permitem disponibilizar o manuscrito como fonte segura para novos e variados estudos.

A edição da cópia da carta régia de 1755 , primeiro corpus desta pesquisa, tem como objetivo disponibilizar o texto setecentista como uma unidade discursiva complexa e viva, que permita o reconhecimento de 
aspectos linguístico-discursivos nas práticas sociais mediadas pela escrita (Marcotulio et al., 2018, p. 14). Para assegurar que esta unidade discursiva mantenha vivas - e apropriadas para estudos linguísticos - as formas originais utilizadas como sistema de pontuação, mais especificamente as vírgulas, optou-se por adotar, neste estudo, a edição semidiplomática do manuscrito, modernamente indicada para reproduzir documentos nos quais se pretenda estudar a história da língua portuguesa (CAMBRAIA, 2005), justamente por ser uma edição conservadora, garantindo alto grau de fidelidade ao modelo, e ao mesmo tempo por facilitar a leitura a um público pouco acostumado, por exemplo, às abreviaturas e a algumas particularidades gráficas da escrita humanística do século XVIII.

Assim, na segunda parte deste estudo, a edição semidiplomática do manuscrito será publicada. E o leitor, agraciado com a possibilidade de conferir a imagem fac-similar de um documento cujo texto, de valor cultural e de interesse público, considerado por isso uma obra de arte, foi selecionado e restaurado por filólogo curador ${ }^{1}$, para ser apresentado ao público.

Para compor o segundo corpus da pesquisa, utilizaremos duas fontes metalinguísticas: As Regras da língua portuguesa, espelho da língua latina $^{2}$, de Dom Jerônimo Contador de Argote, em sua segunda edição, de 1725; e a Ortografia ou arte de escrever, e pronunciar com acerto a língua portuguesa $^{3}$, de João de Moraes Madureira Feijó, de 1734. A escolha se justifica pela representatividade dessas fontes de ideias linguísticas vigentes no português clássico e início do português moderno, a qual tem sido atestada por vários autores, conforme Rodrigues e Gonçalves (2020, p. 228), e ainda pelo pressuposto de que o autor do manuscrito possa ter entrado em contato com essas normas.

1 Termo proposto por Gumbrecht, indicando a noção de que a filologia é "uma curadoria de texto histórico" (FERREIRA, 2016).

2 Disponível em: http://purl.pt/10

3 Disponível em: http://purl.pt/13

Confluência. Rio de Janeiro: Liceu Literário Português, n. 61, p. 8-47, jul.-dez. 2021 
Os dois compêndios sinalizam a importância dada ao latim clássico, imitado e valorizado pela norma culta da língua portuguesa fixada no século XVIII, seguindo a tendência universalista das normas das línguas. Os autores das gramáticas setecentistas argumentam que as regras do português e do latim são, em sua maioria, equivalentes. Segundo Rodrigues e Gonçalves (2020, p.237):

Baseadas no raciocínio e nas operações do espírito, no século XVII francês, surgiram as chamadas gramáticas filosóficas, como a Gramática de Port-Royal (1660) e a Lógica (1662), cujo método de análise da língua ancorava-se na filosofia cartesiana e na crença de que língua é racional e lógica e, por isso, a gramática se caracterizaria por ser algo universal e comum a todas as línguas.

Cardeira (2006, p. 76) argumenta que no século XVIII as questões ortográficas tornam-se um tema polêmico e muito debatido e as propostas dividem-se entre a tradição gráfica, a etimologia e a realidade fonética. Leite (2011, p. 667), por sua vez, salienta o pioneirismo de Argote na sistematização, embora ainda imperfeita, dos dialetos portugueses (continentais, insulares e ultramarinos). Já a ortografia de Feijó, segundo Kemmler ${ }^{4}$ (2001 citado por Coelho e Fontes, 2014, p. 458), chegou a ser o tratado ortográfico com o maior êxito, até inclusive no século XIX.

Na terceira parte da pesquisa, o leitor será convidado a saltar para a página 351 das regras de Argote, onde ele inicia o terceiro capítulo com a conceituação de pontuação. Nas três páginas seguintes, estão catalogadas as regras de uso da vírgula. Na ortografia de Feijó, avançaremos para as páginas 124 e 125, que tratam do uso da vírgula, no capítulo intitulado: $D a$

4 Kemmler, Rolf(2001), "Para uma história da ortogra, a portuguesa: o texto metaortográfico e a sua periodização do século XVI até à reforma ortográfica de 1911", Lusorama Nr. 4748 (Oktober 2001), pp. 128-319.

Confluência. Rio de Janeiro: Liceu Literário Português, n. 61, p. 8-47, jul.-dez. 2021 
Pontuaçam. Do recorte desses dois excertos, apresentaremos uma transcrição ${ }^{5}$ semidiplomática, na qual serão atualizados apenas os alógrafos contextuais de caracteres, de acordo com o alfabeto atual, intervenção suficiente para a fluência da leitura por todos os tipos de leitores.

Mas não só isso. Sublinharemos também a importância da verificação das características gráficas e ortográficas dessas fontes metalinguísticas para a análise da datação paleográfica e da autenticação diplomática do manuscrito, a partir do percurso histórico dos sinais de pontuação e das marcas filológicas características do século XVIII, presentes nos dois corpora, ilustrando que "o método filológico apoia a análise linguística, ao fornecer com critérios um texto fidedigno. Por outro lado, elementos linguísticos do texto estabelecido permitem - e têm sempre permitido estudar a língua aí documentada”. (Telles, 2016).

A quarta e última parte tratará de relacionar o funcionamento do emprego das vírgulas no manuscrito, devidamente editado, com as prescrições presentes nos dois compêndios, contrapondo os critérios e os usos.

\section{O manuscrito como bem cultural e patrimonial do século XVIII}

O texto, manuscrito ou impresso, é o objeto fundamental da investigação histórica, filológica e literária.

Quando e onde o documento foi escrito? Como foi escrito? Quem o escreveu, e por quê? Por onde circulou e onde ficou guardado? Como chegou à contemporaneidade? $\mathrm{O}$ resultado da análise simultânea desses aspectos, a partir da codicologia, da paleografia e da diplomática, é que pode atribuir a um manuscrito o seu caráter de fonte histórica.

5 Cambraia (2005, p. 111) distingue edição e transcrição: "editar significa realizar um conjunto complexo de operações das quais fazem parte não apenas a transcrição mas também a proposição de conjecturas, a seleção de variantes (em uma ed. crítica), a apresentação do texto, etc."

Confluência. Rio de Janeiro: Liceu Literário Português, n. 61, p. 8-47, jul.-dez. 2021 
Vamos iniciar a caracterização filológica da carta-régia de 1755 , copiada e autenticada em 1777, a partir da análise de sua autenticidade como documento diplomático.

\subsection{Autenticidade: elementos diplomáticos}

Conforme Lose (2017, p. 80), os documentos antigos, em grande parte, são também documentos históricos, muitas vezes, porque dizem respeito a momentos, passagens e personagens cujos fatos e ações foram emblemáticos e relevantes e o tempo se encarregou de dar a eles esse atributo. Muito estudado e amplamente divulgado é o acontecimento histórico do dia $1^{\circ}$. de novembro de 1755, um terremoto, seguido de maremoto e incêndio, que destruiu boa parte da cidade de Lisboa. O tremor atingiu altas magnitudes e causou o maremoto que se seguiu. Nas áreas que não foram afetadas pelo tsunami, o fogo das velas acesas em casas e igrejas, pela celebração do dia de Todos os Santos, se alastrou, causando incêndios que duraram dias. Além disso, o terremoto se faz sentir até os dias atuais, em reflexões religiosas, científicas, filosóficas e políticas ${ }^{6}$.

A data do documento - 16 de dezembro de 1755 - revela que, havendo passado pouco mais de um mês do terremoto, o rei D. José I já se dirigia às câmaras das capitanias do Brasil, comunicando esse infeliz acontecimento e solicitando ajuda para a reconstrução da capital dos reinos.

Entretanto, a mera presença, no texto, da notícia do terremoto, não é por si só suficiente para comprovar a autenticidade do documento. $\mathrm{O}$ que confere ao manuscrito a garantia de tratar-se de uma autêntica carta régia espécie documental relevante na dinâmica administrativa colonial do século XVIII, não só pela frequente circulação, registrada nos catálogos dos arquivos portugueses e brasileiros, mas principalmente por sua eficácia ao fazer

6 Bastidores do terremoto de Lisboa, 265 anos depois (FELIPE e CHAUVIN, 2020). Disponível em : https://jornal.usp.br/?p=328861, consultado em 15 de junho de 2020.

Confluência. Rio de Janeiro: Liceu Literário Português, n. 61, p. 8-47, jul.-dez. 2021 
cumprir as ordens que vinham escritas, apesar da distância entre a metrópole e a colônia - são os seus aspectos diplomáticos: i) a estrutura textual da espécie documental carta régia, que segue as fórmulas estabelecidas para uma ordem real, expedida pelo soberano e por ele assinada, presentes neste manuscrito, ou seja: protocolo (“Eu, El Rey, vos envio muito saudar”); objeto ou tema (o pedido de ajuda do rei às câmaras da capitania de Minas Gerais, para a reconstrução de Lisboa); e protocolo final (subscrição: "Rey"); e ii) a sua forma jurídico-administrativa, definida por Bellotto (2002, p. 54) como um documento diplomático, jurídico; dispositivo normativo, que manifesta a vontade da autoridade suprema e que deve obrigatoriamente ser acatado pelos subordinados; e descendente, ou seja, do Rei aos súditos, da instância mais alta às instâncias inferiores.

Além disso, o documento, que compõe o códice registrado no $\mathrm{IEB}^{7}$ como AL 014-002, do acervo Alberto Lamego, é uma cópia autorizada, que surte os mesmos efeitos do original. As assinaturas do escrivão Custódio dos Anjos Fremes, e do tabelião Thomas de Aquino de Figueiredo, identificadas com sinais públicos, validam a força jurídica do original na cópia.

Todas essas propriedades diplomáticas distinguem o manuscrito como fonte documental. Resta ainda analisar os elementos codicológicos e paleográficos, presentes no manuscrito, para investigar a sua genuinidade, marca fundamental para que um texto possa ser utilizado com segurança e credibilidade em futuras pesquisas.

\subsection{Marcas de preservação: elementos codicológicos}

Todo pesquisador reivindica ter o manuscrito em mãos para proceder ao estudo das suas características codicológicas e para investigar, diretamente no testemunho, com os próprios sentidos, as marcas culturais que compõem a materialidade do documento.

7 Instituto de Estudos Brasileiros da Universidade de São Paulo - www.ieb.usp.br 
Almada (2014, p. 141) defende que as marcas deixadas nos suportes são informações preciosas sobre as formas de uso, apropriação, circulação e práticas de preservação do testemunho escrito.

Também para Ackel (2019, p. 39):

Pensar no manuseio de um documento como processos de interferência na formação de sua identidade, utilidade, posse, é entender sua função. Anotações de terceiros, furos nas cartas, rasgos e outras interferências podem representar camadas de identidade documental. A cada estágio de modificação substancial do documento, sua identidade se reconfigura e ele passa a possuir diferentes utilidades. A serventia de uma informação é definida a partir do interesse que se tem sobre ela.

Da observação direta do documento depositado no Instituto de Estudos Brasileiros da Universidade de São Paulo (IEB-USP), e é preciso frisar - trata-se da cópia autenticada do manuscrito de 1755, produzida em 1777 - foi possível identificar aspectos do códice e do testemunho que podem ser analisados como sinais da intencionalidade de preservar e transmitir esse documento a gerações futuras. É possível notar, por exemplo, que a câmara da Vila Real de Sabará utilizou papel de ótima qualidade ${ }^{8}$ para produzir essa cópia, pois ela continua bem conservada, mesmo após 240 anos da produção do manuscrito. Conforme costume da época, várias vias de um documento eram remetidas em datas e embarcações diferentes, para garantir que ao menos uma delas chegasse em segurança ao destino, como foi o caso deste testemunho, que voltou de Portugal no início do século XX, pelas mãos do colecionador brasileiro Alberto Lamego, informação recolhida do próprio catálogo da coleção, que também informa sobre o pouso do códice por

8 Papel de trapos, de boa gramatura, semelhante à do papel vergê $120 \mathrm{~g}$, na cor originalmente bege; presença de vergaturas (de $1 \mathrm{em} 1 \mathrm{~mm}$ ) e pontusais ( 8 por fólio, a cada $26 \mathrm{~mm}$ ); presença de marca d'água, evidenciando um brasão com árvore no cimo, enfeitada com rolos de papiro, e as letras HCW \& Zoonen, indicando as iniciais do nome do fabricante holandês do papel.

Confluência. Rio de Janeiro: Liceu Literário Português, n. 61, p. 8-47, jul.-dez. 2021 
quinze anos, em sua casa. A transferência de toda a coleção para a Biblioteca da então recém-inaugurada Faculdade de Filosofia, Ciências e Letras da Universidade de São Paulo, em 1935, também se faz notar pelo carimbo registrado no manuscrito e por anotações tardias, a lápis, no suporte. Em 1968, o códice foi acondicionado, com tratamentos profissionais de guarda, conservação e restauro, no IEB. Catalogado de maneira a ser mais facilmente acessado, inclusive virtualmente, o documento encontra-se agora disponível para consulta digital nas principais bibliotecas especializadas do Brasil e de Portugal (anotações tardias fazendo transparecer os números do código de registro no catálogo). Por fim, mais um passo para a sua preservação e longevidade, torna-se agora a sua publicação, em novo suporte, a partir da reprodução fac-similar e da edição semidiplomática do manuscrito.

A associação das informações sobre as propriedades materiais do testemunho e sobre a história da sua circulação e transmissão, resultado desta sucinta análise codicológica, constitui mais uma etapa para a verificação e comprovação da autenticidade do documento do século XVIII.

\subsection{Decifração paleográfica: leitura, análise e história da escrita}

A próxima etapa para se avaliar a autenticidade do manuscrito e se fixar a sua forma genuína consiste na sua localização no tempo e no lugar, a partir da análise paleográfica, que prevê a leitura atenta do texto, a descrição do alfabeto, a análise dos traços da escrita e do escrivão, e a associação desses dados com a história social da escrita.

O texto, escrito em português, com o alfabeto da escrita humanística, garante já na primeira leitura um grande aproveitamento de sílabas, palavras e frases, mesmo por leitores pouco especializados. Os traços de cursividade, como a velocidade da escrita e a falta de fronteira entre algumas palavras, não chegam a impedir o leitor moderno de ler e compreender os termos da carta. A única abreviatura utilizada no texto - "q" - pode ser desdobrada em "que", 
facilmente, pelo leitor. As pequenas dificuldades de compreensão do léxico podem ser resolvidas pela consulta a dicionários atuais ${ }^{9}$. Possivelmente, a única dificuldade encontrada pelo leitor seria a identificação dos alógrafos de "s" e de "h", presentes com regularidade em textos setecentistas, e que podem ser decodificados a partir de uma descrição bem feita do alfabeto. Na edição semidiplomática, esses alógrafos serão atualizados.

A análise da execução da escrita, que mostra leveza, letras de módulo pequeno, corridas, traçadas quase sem descanso na mão, com ângulo inclinado à direita, ductus cursivo, e dos hábitos de escrita, como a falta de fronteira entre palavras, principalmente dos clíticos, além da escassez de abreviaturas, evidencia um modelo de escrita humanística cursiva ou italiana, praticada no século XVIII.

Do mesmo modo, esses estudos paleográficos revelam fórmulas de escrita que podem contribuir para estudos sobre as práticas gráficas e sobre o uso que se fazia da língua portuguesa nesse contexto administrativo: i) as grafias etimologizadas (omnipotente, villa, officiaes, aquella, nellas, vassallos, promptamente, occasiã̃, elleiçaõ, escripta, settecentos, assignei); ii) o hífen duplo ao final da linha, indicando separação de sílabas; iii) a sinalização do diacrítico 'til' na vogal $<0>$, e não na vogal $<\mathrm{a}>$, na formação do ditongo "ão"; iv) o sinal "//" para indicar o encerramento da carta (Rey//) e para delimitar o trecho em que aparece a assinatura do escrivão (//Custodio dos Anjos Fremes//); v) a variabilidade nos usos dos ditongos ey/ei, como em Rey e reinos; vi) o uso da desinência "aõ" e não "am", em verbos na $3^{\text {a }}$

9 O leitor pode estranhar o uso da palavra "propensões" no gênero masculino, marcado pelo adjetivo "honrosos", que a precede. Os dicionários contemporâneos ao manuscrito registram a palavra como substantivo feminino. Nas regras de Argote, encontramos, às páginas 293/294, uma possível explicação para esse uso. A descrição do dialeto de Entre Douro e Minho - em relação ao dialeto de Estremadura, eleito como norma culta (CARDEIRA, 2006, p. 76) - mostra que os falantes daquela região pronunciam "aõ" como om. E "fazem a alguns nomes masculinos femininos, e aos femininos, masculinos". Podemos conjecturar uma marca dialetal do escrivão na escrita.

Confluência. Rio de Janeiro: Liceu Literário Português, n. 61, p. 8-47, jul.-dez. 2021 
pessoa do plural dos pretéritos perfeito e imperfeito do indicativo; vii) o sinal diacrítico "til" na vogal "u", para indicar nasalidade, como em "hũ"; e viii) possíveis sinais de oralidade na escrita: desaseis, terromoto, reideficada. E ainda o uso dos reclames, repetição da última palavra de um fólio no início do fólio seguinte, recurso que facilita a recuperação da leitura, na mudança de páginas, substituindo a numeração.

$\mathrm{Na}$ análise relacionada à história social da cultura escrita, o próprio manuscrito responde a perguntas como quem escreveu e por que foi escrito, como bem nos lembra Petrucci (1970). A habilidade do escrivão, que reproduz escrita regular quanto ao traçado das letras, tamanho padronizado, respeito à pauta e às linhas imaginárias, sem rasuras, e sem traços individualizantes da escrita humanística, caracteriza uma prática de escrita regular entre o grupo dos amanuenses das sedes administrativas tanto de Portugal quanto do Brasil, no século XVIII.

Segundo Magalhães (2014, p. 7), os escrivães eram oficiais sempre presentes nas comarcas das capitanias do Brasil, acompanhando os detentores de poder, agindo em representação ou sendo eles próprios autoridades delegadas. Em estudo sobre a relação entre escrita e municipalismo no Brasil colônia ao longo do século XVIII, Magalhães constata que os municípios foram instâncias de ordenamento, poder e decisão, por estatuto próprio e por delegação régia.

Nessa história escrita à mão (Lose, 2017), a carta régia, produzida em 1755, e copiada em 1777, fundamenta o papel social e político dos membros da câmara da Vila Real de Sabará, inclusive do escrivão. A carta régia que chegou à câmara da Vila Real de Sabará transmitia uma ordem real, a qual foi cumprida pelos súditos, sob o comando do governador da capitania de Minas Gerais. Já em 1777, quando foi copiada para ser anexada à representação que solicitava o fim do imposto, expõe, segundo Russel Wood (1998, p.189 e 192), o papel que os governantes das colônias começaram a assumir, de mediadores entre a vontade real e os interesses locais. 


\section{A edição semidiplomática como resultado dos estudos filológicos do manuscrito}

Conforme Vasconcelos \& Santiago-Almeida (2012, p. 351), é de suma importância que a edição de manuscritos siga um rigor científico, caso contrário, muitas dessas edições transcritas aleatoriamente representam uma perda incalculável para o estudo filológico e, consequentemente, para a reconstituição da história interna e da história social da língua portuguesa.

Por isso, levando em conta o público-alvo, a princípio, presumidamente, de pesquisadores da história, da linguística e da história da língua, e o objetivo deste estudo, que se baseia na análise do funcionamento do sistema de pontuação, particularmente das vírgulas, no manuscrito, a presente edição semidiplomática - justalinear com a edição fac-similar do fólio 1 (recto e verso) do documento - se propõe a seguir as normas de transcrição de documentos manuscritos e impressos do Projeto para a História do Português Brasileiro. A mediação dos editores na modernização dos casos de fronteiras de palavras continua preservando a língua original do texto escrito, imprescindível para os estudos linguísticos, sem impedir, aos historidores e aos leitores menos especializados, o acesso ao conteúdo do texto. Além disso, na edição:

a) A transcrição será conservadora;

b) A única abreviatura presente no manuscrito será desenvolvida, marcando-se - em itálico - as letras omitidas, respeitando a grafia do manuscrito;

c) A pontuação original será rigorosamente mantida.

d) A acentuação original será rigorosamente mantida, inclusive a sua posição, não se permitindo qualquer alteração;

e) Será respeitado o emprego de letras maiúsculas e minúsculas, como se apresentam no original. No caso de alguma variação física dos sinais gráficos resultar de fatores cursivos, não será considerada relevante. Assim, a comparação do traçado da mesma letra deve propiciar a melhor solução; 
f) Eventuais erros do escriba ou do copista serão remetidos para nota de rodapé, ao lado da lição correta, da seguinte forma: "epaço" por "espaço";

g) Intervenções de terceiros no documento original serão indicadas em nota de rodapé;

h) A divisão das linhas do documento original será preservada, ao longo do texto. A mudança de fólio receberá a marcação com o respectivo número na sequência de duas barras verticais: ||1r|| ||1v\|| ||2r|| ||2v\|.

i) $\mathrm{Na}$ edição, as linhas serão numeradas de cinco em cinco, a partir da quinta. Essa numeração será encontrada à margem direita da mancha, à esquerda do leitor. Será feita de maneira contínua por documento.

j) As assinaturas simples ou rubricas serão sublinhadas. Os sinais públicos serão sublinhados e indicados entre colchetes. Exemplo: assinatura simples - Bernardo Jose de Lorena; sinal público [Bernardo Jose de Lorena];

k) Os alógrafos contextuais de caracteres são uniformizados segundo o alfabeto atual. 


\subsection{O manuscrito}

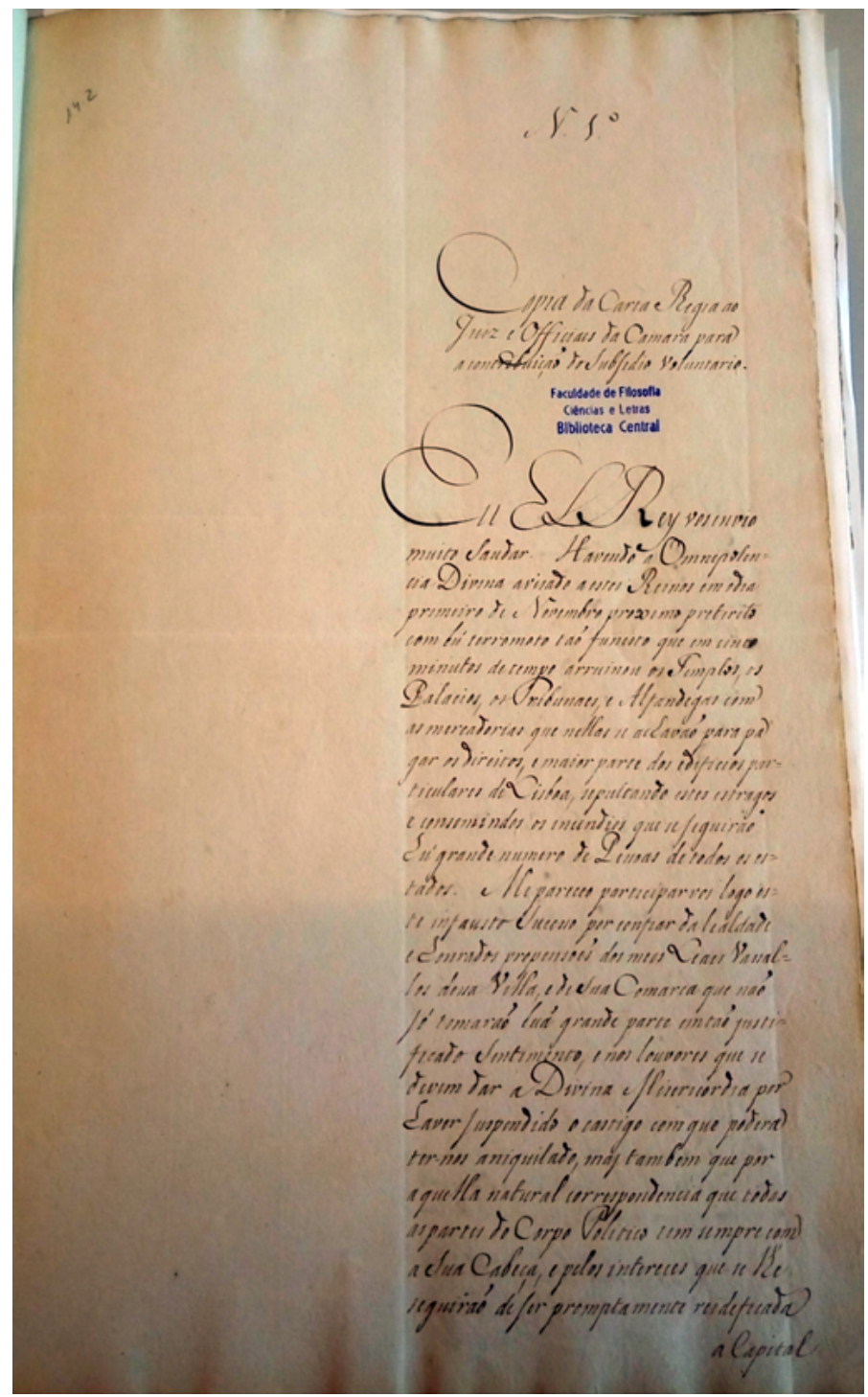

Figura 1. Fac-símile da Carta Régia - fólio 1 - recto

Fonte: Reprodução fotográfica do testemunho do arquivo do IEB-USP, pelos autores.

Confluência. Rio de Janeiro: Liceu Literário Português, n. 61, p. 8-47, jul.-dez. 2021 
$\begin{array}{lllr}\|1 \mathrm{r}\|^{10} & \text { Número } 1^{\mathrm{o}} & & \\ & & & \\ & \text { Copia da Carta } & \text { Regia } & \text { ao } \\ & \text { Juiz e Officiaes da } & \text { Camara } & \text { para } \\ & \text { a contribuiçaõ do Subsidio voluntario }\end{array}$

11

$5 \quad \mathrm{Eu} \quad \mathrm{El} \quad$ Rey vos envio muito saudar. Havendo a Omnipoten= cia Divina avisado a estes Reinos em o dia primeiro de Novembro proximo preterito com hũ terromoto taõ funesto que em cinco

10 minutos de tempo arruinou os Templos, os Palacios, os Tribunaes, e Alfandegas com as mercadorias que nellas se achavaõ para pa gar os direitos, e maior parte dos edificios par= ticulares de Lisboa, sepultando estes estragos

15 e consomindos ${ }^{12}$ os incendios que se seguiraõ hũ grande numero de Pessoas de todos os es= tados. Me pareceo participar vos logo es= te infausto Sucesso por confiar da lealdade e honrados propensoẽs dos meos Leais Vassal=

20 los dessa Villa, e de sua Comarca que naõ só tomaraõ huã grande parte em taõ justi= ficado Sentimento, e nos louvores que se devem dar a Divina Misericordia por haver suspendido o castigo com que podera

25 ter-nos aniquilado, mas tambem que por aquella natural correspondencia que todas as partes do Corpo Politico tem sempre com a Sua Cabeça, e pelos intereces que se lhe seguiraõ de ser promptamente reideficada

10 Presença de anotação tardia: 14.2 , a lápis, na margem esquerda superior, na altura da linha onde consta "N 10 ".

11 Presença de carimbo retangular: Faculdade de Filosofia Ciências e Letras Biblioteca Central

12 "consomindos" por "consomindo"

Confluência. Rio de Janeiro: Liceu Literário Português, n. 61, p. 8-47, jul.-dez. 2021 
Crítica textual e transparência dos traços linguísticos: as vírgulas de um manuscrito setecentista

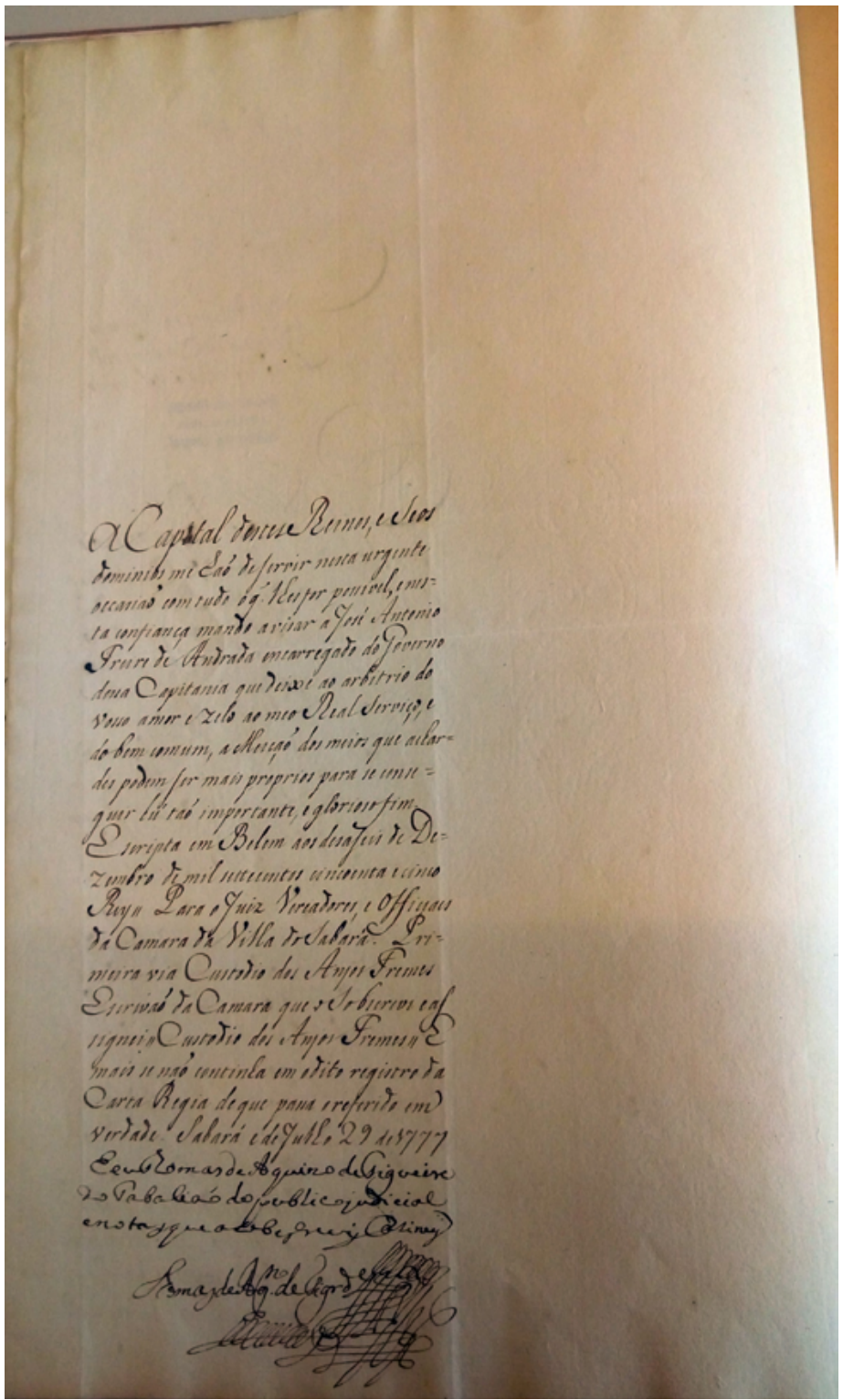

Figura 2. Fac-símile da Carta Régia - fólio 1 - verso.

Fonte: Reprodução fotográfica do testemunho do arquivo do IEB-USP, pelos autores.

Confluência. Rio de Janeiro: Liceu Literário Português, n. 61, p. 8-47, jul.-dez. 2021 
$\|1 \mathrm{v}\| \mathrm{a}$ Capital destes Reinos, e Seos dominios me haõ de servir nesta urgente occasiaõ com tudo o que lhes for possivel, e nes= ta confiança mando avisar a José Antonio

35 Freire de Andrada encarregado do Governo dessa Capitania que deixe ao arbitrio do vosso amor e zelo ao meo Real Serviço, e do bem comum, a elleiçaõ dos meios que achar= des podem ser mais proprios para se conse=

40 guir hũ taõ importante, e glorioso fim. Escripta em Belem aos desaseis de De= zembro de mil settecentos cincoenta e cinco Rey // Para o Juiz Vereadores, e Officiaes da Camara da Villa do Sabará. Pri=

45 meira via Custodio dos Anjos Fremes Escrivaõ da Camara que o Sobscrevi e as signei// Custodio dos Anjos Fremes// E mais se naõ continha em o dito registro da Carta Regia de que passa o referido em

50 Verdade. Sabará e de Julho 29 de 1777 E eu Thomas de Aquino de Figueire do Tabaliaõ do publico judicial e notas que o Sobescrevi e asiney [Thomas de Aquino de Figueiredo] [Custódio dos Anjos Fremes]

\section{A crítica textual e a transmissão fidedigna do manuscrito}

Apesar do consenso sobre a imprescindibilidade de uma transcrição extremamente fidedigna e cuidadosa para deixar transparentes todos os traços linguísticos possíveis de serem analisados nos originais manuscritos (VASCONCELOS \& SANTIAGO-ALMEIDA, 2012, p. 351), a fim de que o estudo específico obtenha êxito, nem sempre os estudiosos linguistas se 
deparam com o devido rigor científico de uma edição, especialmente quando buscam explicações para o uso dos sinais de pontuação. Os motivos são variados, atingem documentos manuscritos e impressos, e refletem tanto a necessidade da intermediação do filólogo-editor, diante de cópias ou originais de difícil interpretação, no processo de fixação do texto, como os erros de cópia, a que, segundo Blécua (1990), todas as pessoas que escrevem estão sujeitas, no processo de transmissão do texto.

Dahlet (2006, p. 292) esclarece que "sob o efeito da imprensa, a pontuação veio se formalizando, se regulando, até o século XIX, quando reinava certa anarquia no modo como os editores pontuavam os textos dos autores que publicavam".

Dois exemplos ilustram que essa situação perdura ainda até o século XXI. No primeiro texto, vemos a autora Clarice Lispector, em carta de 7 de março de 1955, tendo que enfatizar ao seu tradutor francês que nada deveria ser modificado no seu texto:

[...] eu tomei liberdades de estilo, o que dá direito de criticar, mas não de impedir. [...] Eu gostaria ainda de esclarecer o seguinte: a pontuação que eu empreguei no livro não é acidental e não resulta da ignorância de regras gramaticais. Você concordaria comigo que os princípios elementares de pontuação são aprendidos em qualquer escola. Estou plenamente consciente das razões que me levaram a escolher essa pontuação e faço questão que ela seja respeitada. (Arquivo Museu de Literatura Brasileira, Fundação Casa Rui Barbosa apud MENDES e AMBROSILI, 2015, p. 10).

O segundo texto ironiza a postura do revisor, que muitas vezes oscila entre a displicência e a atitude "colaborativa", quando se supõe autorizado a modificar o texto original, desconsiderando totalmente o ponto de vista do autor. Trata-se de parte do artigo intitulado "A reinvenção da vírgula" 13 :

13 RENOVATO, J. Publicado no Jornal da USP, em 28/08/2019, o texto foi utilizado numa das questões de língua portuguesa da $2^{\mathrm{a}}$ fase da FUVEST de 2020.

Confluência. Rio de Janeiro: Liceu Literário Português, n. 61, p. 8-47, jul.-dez. 2021 


\begin{abstract}
No nosso caso, o erro não foi nada de mais, nem erro foi para falar a verdade, apenas um acréscimo besta de pontuação, talvez dispensável, ainda que de modo algum incorreto. Vai o revisor, fiel à ortodoxia da gramática normativa, e espeta duas vírgulas para isolar um adjunto adverbial deslocado, coisa de pouca monta, diria alguém, mas suficiente para o autor sair bradando aos quatro ventos que lhe roubaram o ritmo da sentença.
\end{abstract}

Toda esta argumentação sobre a probabilidade de um texto perder ou ganhar sequer uma vírgula ${ }^{14}$, durante a sua transmissão, visa a destacar o papel essencial da crítica textual e a reafirmar o compromisso destes editores com os cuidados praticados na restituição da forma genuína da cópia da carta régia, a fim de que possa ser utilizada como fonte confiável para o estudo linguístico pretendido.

Como o manuscrito que temos em mãos é uma cópia, ainda que autenticada, podemos presumir alguma divergência, inclusive nos sinais de pontuação, em relação à versão original, de 1755, testemunho ao qual, até o momento, não tivemos acesso. Ainda assim, consideramos que os resultados da análise da pontuação no manuscrito produzido em 1777 não serão prejudicados por esse motivo.

\title{
3.1 Os compêndios ortográficos do século XVIII: prescritivos e filológicos
}

A representatividade das fontes metalinguísticas assinadas por Argote e por Feijó não foi o único parâmetro utilizado para a composição do repertório desta pesquisa. A presença, em cada um dos compêndios, de um capítulo exclusivo dedicado à pontuação, foi imprescindível para se realizar a análise pretendida, que deseja investigar de que forma o escrivão

14 Vírgula é palavra diminuta de virga, que significa a vara, como huma varinha torcida, que nasce do fim da palavra (Feijó, 1735, p. 124).

Confluência. Rio de Janeiro: Liceu Literário Português, n. 61, p. 8-47, jul.-dez. 2021 
que produziu o manuscrito, em 1755, lidava com as prescrições sobre a utilização das vírgulas.

Banza e Gonçalves (2018, p. 42) destacam a importância dos compêndios do século XVIII:

A importância destas obras para a história da língua portuguesa é incontornável: como fontes primárias, enquanto testemunhos directos da escrita, como fontes secundárias, enquanto documentos metalinguísticos, mas também como testemunho de uma valorização das línguas vernáculas a que não é, naturalmente, alheio o movimento humanista do Renascimento.

Prescritivos, os dois tratados gramaticais do século XVIII orientam os leitores a escrever e a ler com correção. Para além dessa função metalinguística, carregam em suas páginas tradições gráficas e ortográficas que vêm de séculos anteriores, mas que permanecem como modelos da escrita setecentista. Podemos dizer que aspectos paleográficos presentes nos manuscritos ${ }^{15}$ e levados, pela tipografia, aos impressos metalinguísticos, são marcas filológicas que também possibilitam conjecturar sobre a datação do manuscrito. Como exemplos, citamos: i) a permanência dos reclames nas páginas que já contam com o sistema de numeração" 16 ii) a grafia do "s" longo, que lembra um rebuscamento manual, e permanece na tipografia até o final do século XVIII ${ }^{17}$; iii) a variabilidade no uso das desinências "aõ" e "am", em substantivos e verbos: pontuação (FEIJÓ, 1734, folha de rosto) e pontuaçam (FEIJÓ, 1734, p. 124); tinhaõ/tiveraõ/tenhã̃, no pretérito imperfeito do indicativo (FEIJÓ, 1734, p. 154); escreverám/pronunciarám, no

\section{Apresentados no item 1.3.}

16 Segundo Dias (2018), a função de orientar a encadernação das páginas ainda era do reclame, daí o uso concomitante da numeração das páginas e dos reclames nos impressos.

17 Conforme pesquisa realizada em 06/06/2020, notamos que o "S" longo ainda está presente nas páginas da ortografia portugueza ou regras para escrever certo, ordenadas para uso de quem se quizer applicar, de Souto Maior (1783); mas já não aparece na grammatica portugueza, de Manuel Dias de Souza (1804).

Confluência. Rio de Janeiro: Liceu Literário Português, n. 61, p. 8-47, jul.-dez. 2021 


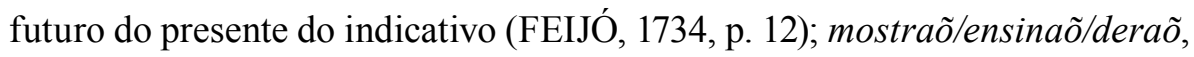
no presente do indicativo (ARGOTE, 1725, p. 351 a 353); e iv) a utilização do sinal diacrítico "til" sobre a letra "o", no ditongo nasal "aõ".

\subsection{Regras da língua portuguesa, espelho da língua latina - Dom Jerônimo Contador de Argote}

As regras de Argote se afiguram em 356 páginas (capítulos introdutórios e prólogo incluídos nesse número de páginas) harmonizadas por um modelo de diálogo socrático ${ }^{18}$, entre o Mestre (M) e o Discípulo (D), em que o discípulo apresenta as regras, mostrando sua capacidade de raciocínio. E o Mestre vai apenas conduzindo os assuntos, com as perguntas.

Lições de morfologia e sintaxe, mais as figuras de sintaxe são apresentadas nas três primeiras partes das "regras da língua portuguesa". A quarta parte, acrescentada nesta segunda edição (a primeira edição é de 1721), apresenta um capítulo sobre os dialetos da língua portuguesa, muito elogiado, até a atualidade, por registrar fatos de uso e não apenas de norma (LEITE, 2011). A seguir, vem um capítulo sobre a ordem das palavras na construção da frase. A parte intitulada Prática da regência da gramática portuguesa conforme com a regência latina, mais uma amostra do pioneirismo de Argote, propõe um exercício prático, a ser seguido como exemplo pelos professores, a partir de uma carta do padre Antonio Vieira, para ensinar gramática aos alunos. Essa novidade antevia a necessidade de se priorizar o ensino da gramática a partir do uso real da língua, num texto, por exemplo. Outra inovação presente em Argote são os exemplos citados. Não são exemplos de obras da tradição literária, mas frases do cotidiano, mostrando o funcionamento de algumas estruturas gramaticais na prática da língua escrita.

18 Conforme Costrino (2020), esses textos em forma de diálogo foram utilizados também por Cícero (aproximadamente em 46 AC), em "Partições da Oratória"; por Agostinho, em "De Magistro" (entre 388 e 391); e por Erasmo de Rotterdam, em “Diálogo Ciceroniano” (1528). 
Por último, Argote apresenta o tratado breve da ortografia, em que define a ortografia como "a arte de escrever as palavras e orações com as letras, e pontuação, com que se devem escrever". O capítulo sobre pontuação é o terceiro dessa parte do tratado, e o último do livro.

Mestre: Tendes mais que dizer da/o Ortografia Portugueza?

Discípulo: Mais há que dizer, mas isto basta.

Esse diálogo, repetido ao fim de cada capítulo, parece encenar um reconhecimento da impossibilidade de se registrar todos os usos e normas gramaticais de uma língua, sempre em mudança.

A transcrição semidiplomática ${ }^{19}$ dos trechos das páginas 351 a 354 reproduzirá fielmente a paragrafação, a grafia, os sinais de acentuação e a pontuação.

19 1. Na transcrição, as linhas são enumeradas de cinco em cinco, a partir da quinta; 2. A posição do acento respeita o mais fielmente possível a sua posição no modelo; 3 . Os alógrafos contextuais de caracteres são uniformizados segundo o alfabeto atual.

Confluência. Rio de Janeiro: Liceu Literário Português, n. 61, p. 8-47, jul.-dez. 2021 
Quadro 1. transcrição semidiplomática das páginas 351 a 354 das Regras da língua portuguesa, espelho da língua latina - Dom Jerônimo Contador de Argote

\begin{tabular}{|l}
\hline \multicolumn{1}{|c}{ C A P I T U L O III. } \\
Da pontuação da Orthografia Portugueza \\
Mestre. Dissestes que o escrever com \\
acerto consistia tambem na Pon- \\
tuação. Que cousa he Pontuaçaõ? \\
D. Pontuaçaõ saõ uns risquinhos, ou \\
pontos, com que se apartaõ entre si \\
as palavras, e mostraõ que casta de \\
sentido fazem. \\
M. Quantas castas ha desses risquinhos, \\
ou pontos? \\
D. Sete. \\
M. Quaes saõ? \\
D. Saõ os seguintes. Virgula, Ponto, e \\
virgula, dous pontos, Ponto, Ponto \\
admiração, Ponto interrogação, \\
Parenthesis. \\
M. Que cousa he virgula? \\
D. He huma figurinha desta sorte \\
... \\
M.
\end{tabular}

continua...

Confluência. Rio de Janeiro: Liceu Literário Português, n. 61, p. 8-47, jul.-dez. 2021 


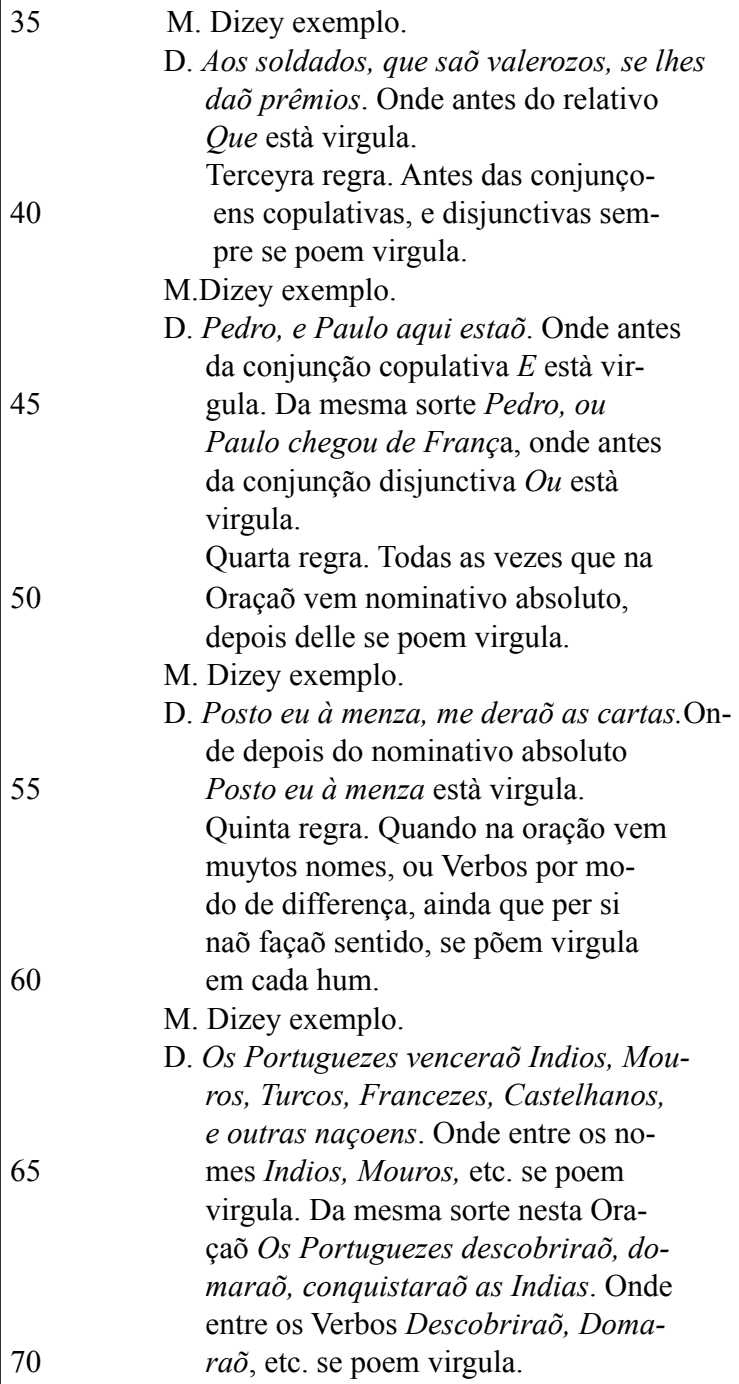

D. Pedro, e Paulo aqui estaõ. Onde antes da conjunção copulativa $E$ està virgula. Da mesma sorte Pedro, ou Paulo chegou de França, onde antes da conjunção disjunctiva $O u$ està virgula.

Quarta regra. Todas as vezes que na Oraçaõ vem nominativo absoluto, depois delle se poem virgula.

M. Dizey exemplo.

D. Posto eu à menza, me deraõ as cartas.Onde depois do nominativo absoluto

55 Posto eu à menza està virgula. Quinta regra. Quando na oração vem muytos nomes, ou Verbos por modo de differença, ainda que per si naõ façaõ sentido, se põem virgula 60 em cada hum

M. Dizey exemplo.

D. Os Portuguezes venceraõ Indios, Mouros, Turcos, Francezes, Castelhanos, e outras naçoens. Onde entre os no65 mes Indios, Mouros, etc. se poem virgula. Da mesma sorte nesta Oraçaõ Os Portuguezes descobriraõ, domaraõ, conquistaraõ as Indias. Onde entre os Verbos Descobriraõ, Doma$70 \quad$ raõ, etc. se poem virgula.

Fonte: Transcrição elaborada pelos autores.

Confluência. Rio de Janeiro: Liceu Literário Português, n. 61, p. 8-47, jul.-dez. 2021 


\subsection{Madureira Feijó e a ortografia, ou a arte de escrever, $e$ pronunciar com acerto a língua portuguesa}

Na ortografia de Feijó, as 553 páginas são divididas em três partes: i) como se escrevem as palavras e como se pronunciam; ii) divisão de palavras e pontuação; numerais romanos e contas de calendas, nonas e idos; e iii) erros do vulgo e emendas da ortografia, no escrever e pronunciar. Capítulos introdutórios e índice estão incluídos nessa quantidade de páginas.

Feijó utiliza verbetes no formato enciclopédico para expor as lições de ortografia. A maior parte do livro lembra um dicionário, onde as palavras são listadas para mostrar tanto a ortografia e pronúncia corretas, como a forma incorreta, para que não se erre mais. O autor deixa recados para os professores, no capítulo: Breve instrução para os mestres das escolas de ler e escrever, sempre frisando a importância de se ensinar a escrita e a pronúncia. Aliás, a preocupação com a pronúncia das palavras percorre toda a ortografia, desde o seu título, e caminha por todas as páginas, lado a lado com a percepção de que as regras que se prescreve não são infalíveis, pois a língua vai se apurando e se aperfeiçoando. As unidades lexicais e os exemplos utilizados, sempre na versão em português e em latim, são contextualizados em fontes históricas, técnicas, científicas, ou literárias.

A transcrição semidiplomática ${ }^{20}$ das páginas 124 e 125, adiante, reproduzirá fielmente a paragrafação, a grafia, os sinais de acentuação e a pontuação.

20 1. Na transcrição, as linhas são enumeradas de cinco em cinco, a partir da quinta; 2. A posição do acento respeita o mais fielmente possível a sua posição no modelo; 3. Os alógrafos contextuais de caracteres são uniformizados segundo o alfabeto atual. 
Quadro 2 - Transcrição semidiplomática das páginas 124 e 125 da Ortografia, ou a arte de escrever, e pronunciar com acerto a língua portuguesa - João de Moraes Madureira Feijó

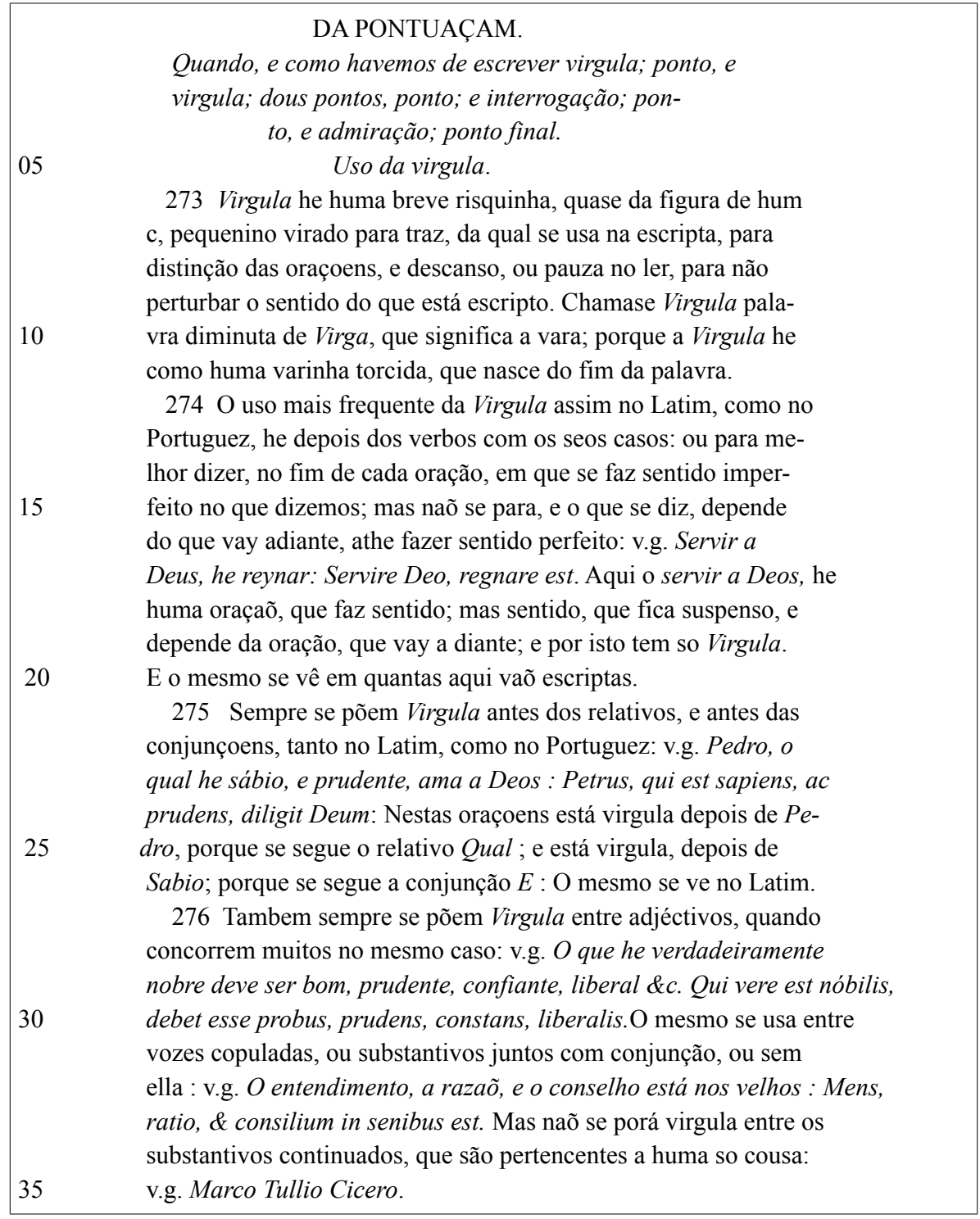

Fonte: Transcrição elaborada pelos autores.

Confluência. Rio de Janeiro: Liceu Literário Português, n. 61, p. 8-47, jul.-dez. 2021 


\section{As prescrições ortográficas para o uso da vírgula}

No quadro a seguir, estão resumidas as regras de uso da vírgula propostas por Argote e por Madureira Feijó.

Quadro 3. Regras para o uso das vírgulas em Argote e Feijó

\begin{tabular}{|c|c|c|}
\hline REGRA & ARGOTE & FEIJÓ \\
\hline 1 & $\begin{array}{l}\text { Entre duas orações cujo sentido } \\
\text { parece imperfeito } \\
\text { Linha } 25\end{array}$ & $\begin{array}{l}\text { Entre duas orações cujo sentido } \\
\text { parece imperfeito } \\
\text { Linha } 13 \text {-verbete } 274\end{array}$ \\
\hline 2 & $\begin{array}{l}\text { Antes dos nomes relativos } \\
\text { Linha } 36\end{array}$ & $\begin{array}{l}\text { Antes dos relativos e das conjunções } \\
\text { Linha } 22 \text {-verbete } 275\end{array}$ \\
\hline 3 & $\begin{array}{l}\text { Antes de conjunções copulativas e } \\
\text { disjuntivas } \\
\text { Linha } 42\end{array}$ & \\
\hline 3 & & $\begin{array}{l}\text { Entre os adjetivos, quando } \\
\text { concorrem muitos no mesmo caso, } \\
\text { com ou sem conjunção; } \\
\text { Entre vozes copuladas, ou } \\
\text { substantivos juntos com conjunção, } \\
\text { ou sem ela. } \\
\text { Linha } 28 \text { - verbete } 276\end{array}$ \\
\hline 4 & $\begin{array}{l}\text { Após o nominativo absoluto } \\
\text { Linha } 52\end{array}$ & \\
\hline 5 & $\begin{array}{l}\text { Muitos verbos ou nomes na } \\
\text { sequência } \\
\text { Linha } 60\end{array}$ & \\
\hline
\end{tabular}

Fonte: Elaborado pelos autores.

Essas regras têm vários pontos de intersecção. Os dois autores concordam que a vírgula deve ser utilizada: para separar frases com sentido imperfeito; antes de pronomes relativos (sem especificação) e antes de 
conjunções $^{21}$; e para separar cada elemento de uma sequência de adjetivos, nomes ou verbos, com ou sem conjunção. Somente Argote cita uma regra específica para separar o nominativo absoluto, uma espécie de oração reduzida, no caso, de particípio, com o pronome pessoal de primeira pessoa do singular.

Os autores dos compêndios explicam o uso das vírgulas baseados em "uma função mais lógico-gramatical, ainda que pouco sistematizada." (RODRIGUES \& GONÇALVES, 2020, p. 238). Embora Feijó (1734, p. 124) destaque a importância da correta pronúncia para se escrever corretamente, e defina vírgula como "huma breve risquinha, quase da figura de hum c, pequenino virado para traz, da qual se usa na escripta, para distinção das oraçoens, e descanso, ou pauza no ler, para não perturbar o sentido do que está escripto", nem ele, nem Argote recomendam qualquer tipo de pausa respiratória como regra para o emprego da vírgula.

\subsection{Quando o escrivão emprega vírgulas}

Passemos, então, à localização das vírgulas utilizadas no texto manuscrito, relacionando esse uso com as regras prescritas pelos compêndios de Argote e de Feijó.

21 Argote restringe o uso da vírgula para as conjunções copulativas e disjuntivas; Feijó, na linha 22, não especifica os tipos de conjunção, mas no exemplo citado apresenta a conjunção copulativa "e". 
Crítica textual e transparência dos traços linguísticos: as vírgulas de um manuscrito setecentista

Quadro 4. Pontuação realizada pelo escrivão, no manuscrito, e a relação desse uso com as regras dos compêndios

\begin{tabular}{|c|c|c|c|}
\hline $\begin{array}{l}\text { Vírgulas utilizadas } \\
\text { no manuscrito }\end{array}$ & linha & Argote & Feijó \\
\hline Templos, & 10 & $\begin{array}{l}\text { Quando na oração vêm } \\
\text { muitos nomes, ou verbos }\end{array}$ & $\begin{array}{l}\text { Entre substantivos e } \\
\text { adjetivos, quando concorrem } \\
\text { muitos no mesmo caso, com } \\
\text { ou sem conjunções. }\end{array}$ \\
\hline Palacios, & 11 & $\begin{array}{l}\text { Quando na oração vêm } \\
\text { muitos nomes, ou verbos }\end{array}$ & $\begin{array}{l}\text { Entre substantivos e } \\
\text { adjetivos, quando concorrem } \\
\text { muitos no mesmo caso, com } \\
\text { ou sem conjunção. }\end{array}$ \\
\hline os Tribunaes, e & 11 & $\begin{array}{l}\text { Antes de conjunções } \\
\text { copulativas }\end{array}$ & $\begin{array}{l}\text { Antes dos relativos e das } \\
\text { conjunções }\end{array}$ \\
\hline os direitos, e & 13 & $\begin{array}{l}\text { Antes de conjunções } \\
\text { copulativas }\end{array}$ & $\begin{array}{l}\text { Antes dos relativos e das } \\
\text { conjunções }\end{array}$ \\
\hline Lisboa, sepultando... & 14 & $\begin{array}{l}\text { Sentido imperfeito entre } \\
\text { duas orações }\end{array}$ & $\begin{array}{l}\text { Sentido imperfeito entre } \\
\text { duas orações }\end{array}$ \\
\hline Villa, e & 20 & $\begin{array}{l}\text { Antes de conjunções } \\
\text { copulativas }\end{array}$ & $\begin{array}{l}\text { Antes dos relativos e das } \\
\text { conjunções }\end{array}$ \\
\hline Sentimento, e & 22 & $\begin{array}{l}\text { Antes de conjunções } \\
\text { copulativas }\end{array}$ & $\begin{array}{l}\text { Antes dos relativos e das } \\
\text { conjunções }\end{array}$ \\
\hline $\begin{array}{l}\text { não só... aniquilado, } \\
\text { mas também }\end{array}$ & 25 & $\begin{array}{l}\text { Antes de conjunções } \\
\text { copulativas }\end{array}$ & $\begin{array}{l}\text { Antes dos relativos e das } \\
\text { conjunções }\end{array}$ \\
\hline Cabeça, e & 28 & $\begin{array}{l}\text { Antes de conjunções } \\
\text { copulativas }\end{array}$ & $\begin{array}{l}\text { Antes dos relativos e das } \\
\text { conjunções }\end{array}$ \\
\hline Reinos, e & 31 & $\begin{array}{l}\text { Antes de conjunções } \\
\text { copulativas }\end{array}$ & $\begin{array}{l}\text { Antes dos relativos e das } \\
\text { conjunções }\end{array}$ \\
\hline possivel, e & 33 & $\begin{array}{l}\text { Antes de conjunções } \\
\text { copulativas }\end{array}$ & $\begin{array}{l}\text { Antes dos relativos e das } \\
\text { conjunções }\end{array}$ \\
\hline Serviço, e & 37 & $\begin{array}{l}\text { Antes de conjunções } \\
\text { copulativas }\end{array}$ & $\begin{array}{l}\text { Antes dos relativos e das } \\
\text { conjunções }\end{array}$ \\
\hline
\end{tabular}




\begin{tabular}{|l|l|l|l|}
\hline $\begin{array}{c}\text { Vírgulas utilizadas } \\
\text { no manuscrito }\end{array}$ & linha & \multicolumn{1}{|c|}{ Argote } & \multicolumn{1}{c|}{ Feijó } \\
\hline comum, a elleiçaõ & 38 & $\begin{array}{l}\text { Sentido imperfeito entre } \\
\text { duas orações }\end{array}$ & $\begin{array}{l}\text { Sentido imperfeito entre } \\
\text { duas orações }\end{array}$ \\
\hline importante, e & 40 & $\begin{array}{l}\text { Antes de conjunções } \\
\text { copulativas }\end{array}$ & $\begin{array}{l}\text { Antes dos relativos e das } \\
\text { conjunções }\end{array}$ \\
\hline Vereadores, e & 43 & $\begin{array}{l}\text { Antes de conjunções } \\
\text { copulativas }\end{array}$ & $\begin{array}{l}\text { Antes dos relativos e das } \\
\text { conjunções }\end{array}$ \\
\hline
\end{tabular}

Fonte: Elaborado pelos autores.

O quadro mostra a ocorrência de dez vírgulas utilizadas no manuscrito antes da conjunção copulativa "e". Uma única vez, a vírgula foi pontuada antes de "mas", na construção também correlativa aditiva "não só, mas também". Em dois momentos, inferimos que o uso da vírgula se deu para separar frases com sentido imperfeito. E em outros dois, as vírgulas separaram os nomes listados sequencialmente. Todas as normas prescritas nos compêndios foram atendidas nestas situações. Ainda assim, não é possível afirmar com toda a certeza que os escrivães liam e seguiam as regras dos tratados ortográficos, ou se as normas é que retratavam o uso que se fazia dos sinais de pontuação na prática escrita.

\subsection{Quando o escrivão não emprega vírgulas}

Quadro 5. A ausência de pontuação, no manuscrito, em contraposição às regras dos compêndios

\begin{tabular}{|l|l|l|l|l|}
\hline $\begin{array}{c}\text { Ausência de } \\
\text { vírgula }\end{array}$ & Linha & $\begin{array}{c}\text { Função sintática } \\
\text { do vocábulo “que” }\end{array}$ & Argote & Feijó \\
\hline $\begin{array}{l}\text { tão funesto } \varnothing \\
\text { que }\end{array}$ & 9 & $\begin{array}{l}\text { Conjunção } \\
\text { subordinativa } \\
\text { consecutiva }\end{array}$ & $\begin{array}{l}\text { Antes dos relativos } \\
\text { e das conjunções }\end{array}$ \\
\hline
\end{tabular}

continua...

Confluência. Rio de Janeiro: Liceu Literário Português, n. 61, p. 8-47, jul.-dez. 2021 
Crítica textual e transparência dos traços linguísticos: as vírgulas de um manuscrito setecentista

\begin{tabular}{|c|c|c|c|c|}
\hline $\begin{array}{c}\text { Ausência de } \\
\text { vírgula }\end{array}$ & Linha & $\begin{array}{c}\text { Função sintática } \\
\text { do vocábulo "que" }\end{array}$ & Argote & Feijó \\
\hline $\begin{array}{l}\text { Mercadorias } \\
\varnothing \text { que nellas }\end{array}$ & 12 & Pronome relativo & $\begin{array}{l}\text { Antes dos nomes } \\
\text { relativos }\end{array}$ & $\begin{array}{l}\text { Antes dos relativos } \\
\text { e das conjunções }\end{array}$ \\
\hline estragos $\varnothing \mathrm{e}$ & 14 & & $\begin{array}{l}\text { Antes de } \\
\text { conjunções } \\
\text { copulativas }\end{array}$ & $\begin{array}{l}\text { Antes dos relativos } \\
\text { e das conjunções }\end{array}$ \\
\hline $\begin{array}{l}\text { incendios } \varnothing \text { que } \\
\text { se seguiraõ }\end{array}$ & 15 & Pronome relativo & $\begin{array}{l}\text { Antes dos nomes } \\
\text { relativos }\end{array}$ & $\begin{array}{l}\text { Antes dos relativos } \\
\text { e das conjunções }\end{array}$ \\
\hline lealdade $\varnothing \mathrm{e}$ & 19 & & $\begin{array}{l}\text { Antes de } \\
\text { conjunções } \\
\text { copulativas }\end{array}$ & $\begin{array}{l}\text { Antes dos relativos } \\
\text { e das conjunções }\end{array}$ \\
\hline $\begin{array}{l}\text { vassalos... Ø que } \\
\text { não }\end{array}$ & 20 & Pronome relativo & $\begin{array}{l}\text { Antes dos nomes } \\
\text { relativos }\end{array}$ & $\begin{array}{l}\text { Antes dos relativos } \\
\text { e das conjunções }\end{array}$ \\
\hline louvores $\varnothing$ que & 22 & Pronome relativo & $\begin{array}{l}\text { Antes dos nomes } \\
\text { relativos }\end{array}$ & $\begin{array}{l}\text { Antes dos relativos } \\
\text { e das conjunções }\end{array}$ \\
\hline $\begin{array}{l}\text { castigo } \varnothing \text { com } \\
\text { que }\end{array}$ & 24 & Pronome relativo & $\begin{array}{l}\text { Antes dos nomes } \\
\text { relativos }\end{array}$ & $\begin{array}{l}\text { Antes dos relativos } \\
\text { e das conjunções }\end{array}$ \\
\hline $\begin{array}{l}\text { vassalos... Ø que } \\
\text { por aquella }\end{array}$ & 25 & Pronome relativo & $\begin{array}{l}\text { Antes dos nomes } \\
\text { relativos }\end{array}$ & $\begin{array}{l}\text { Antes dos relativos } \\
\text { e das conjunções }\end{array}$ \\
\hline $\begin{array}{l}\text { Correspondência } \\
\varnothing \text { que todas }\end{array}$ & 26 & Pronome relativo & $\begin{array}{l}\text { Antes dos nomes } \\
\text { relativos }\end{array}$ & $\begin{array}{l}\text { Antes dos relativos } \\
\text { e das conjunções }\end{array}$ \\
\hline intereces $\varnothing$ que & 28 & Pronome relativo & $\begin{array}{l}\text { Antes dos nomes } \\
\text { relativos }\end{array}$ & $\begin{array}{l}\text { Antes dos relativos } \\
\text { e das conjunções }\end{array}$ \\
\hline $\begin{array}{l}\text { Ø o que lhes for } \\
\text { possível }\end{array}$ & 33 & Pronome relativo & $\begin{array}{l}\text { Antes dos nomes } \\
\text { relativos }\end{array}$ & $\begin{array}{l}\text { Antes dos relativos } \\
\text { e das conjunções }\end{array}$ \\
\hline $\begin{array}{l}\text { Mando avisar...Ø } \\
\text { que deixe ao } \\
\text { arbitrio }\end{array}$ & 36 & $\begin{array}{l}\text { Conjunção } \\
\text { integrante }\end{array}$ & & $\begin{array}{l}\text { Antes dos relativos } \\
\text { e das conjunções }\end{array}$ \\
\hline $\begin{array}{l}\text { Meios } \varnothing \text { que } \\
\text { achardes }\end{array}$ & 38 & Pronome relativo & $\begin{array}{l}\text { Antes dos nomes } \\
\text { relativos }\end{array}$ & $\begin{array}{l}\text { Antes dos relativos } \\
\text { e das conjunções }\end{array}$ \\
\hline
\end{tabular}

continua...

Confluência. Rio de Janeiro: Liceu Literário Português, n. 61, p. 8-47, jul.-dez. 2021 


\begin{tabular}{|c|c|c|c|c|}
\hline $\begin{array}{c}\text { Ausência de } \\
\text { vírgula }\end{array}$ & Linha & $\begin{array}{c}\text { Função sintática } \\
\text { do vocábulo "que" }\end{array}$ & Argote & Feijó \\
\hline $\begin{array}{l}\text { Juiz } \\
\varnothing \text { vereadores }\end{array}$ & 43 & & $\begin{array}{l}\text { Quando na oração } \\
\text { vêm muitos nomes, } \\
\text { ou verbos }\end{array}$ & $\begin{array}{l}\text { Entre substantivos } \\
\text { e adjetivos, quando } \\
\text { concorrem muitos } \\
\text { no mesmo caso, } \\
\text { com ou sem } \\
\text { conjunções. }\end{array}$ \\
\hline $\begin{array}{l}\text { Escrivaõ da } \\
\text { câmara } \emptyset \text { que o } \\
\text { sobscrevi }\end{array}$ & 46 & Pronome relativo & $\begin{array}{l}\text { Antes dos nomes } \\
\text { relativos }\end{array}$ & $\begin{array}{l}\text { Antes dos relativos } \\
\text { e das conjunções }\end{array}$ \\
\hline $\begin{array}{l}\text { Sobscrevi Ø e } \\
\text { assignei }\end{array}$ & 46 & & $\begin{array}{l}\text { Antes de } \\
\text { conjunções } \\
\text { copulativas }\end{array}$ & $\begin{array}{l}\text { Antes dos relativos } \\
\text { e das conjunções }\end{array}$ \\
\hline $\begin{array}{l}\text { Registro... } \varnothing \text { de } \\
\text { que passa }\end{array}$ & 49 & Pronome relativo & $\begin{array}{l}\text { Antes dos nomes } \\
\text { relativos }\end{array}$ & $\begin{array}{l}\text { Antes dos relativos } \\
\text { e das conjunções }\end{array}$ \\
\hline$\varnothing$ e notas & 53 & & $\begin{array}{l}\text { Antes de } \\
\text { conjunções } \\
\text { copulativas }\end{array}$ & $\begin{array}{l}\text { Antes dos relativos } \\
\text { e das conjunções }\end{array}$ \\
\hline $\begin{array}{l}\text { E eu ... Ø que o } \\
\text { sobescrevi }\end{array}$ & 53 & Pronome relativo & $\begin{array}{l}\text { Antes dos nomes } \\
\text { relativos }\end{array}$ & $\begin{array}{l}\text { Antes dos relativos } \\
\text { e das conjunções }\end{array}$ \\
\hline
\end{tabular}

Fonte: Elaborado pelos autores.

No quadro 5, observamos treze ocorrências de pronomes relativos, nenhuma delas pontuada com vírgula, como se a ausência de vírgulas antes dos relativos é que fosse uma regra para o escrivão. Notamos esse procedimento também na linha 9, diante de uma conjunção subordinativa consecutiva, e na linha 36, diante de uma conjunção integrante, ocorrências que, segundo Feijó, deveriam ser precedidas por vírgulas.

À primeira vista, essa ausência de vírgulas, no manuscrito, diante de casos tão claramente prescritos pelos ortografistas, pode levar à conclusão simplista de que o escrivão definitivamente não segue as normas dos 
compêndios. Porém, se considerarmos o estudo de Chacon (1998) sobre as dimensões da linguagem que vinculam o ritmo próprio da escrita à maneira como os gramáticos preconizam o emprego da pontuação e da construção do ritmo da escrita, veremos que há uma concordância entre o manuscrito e as ortografias setecentistas.

Em Argote e Feijó, podemos identificar a dimensão sintática, ou seja, os autores demonstram uma preocupação com a delimitação de unidades da escrita, definidas pelo seu papel sintático, por exemplo, quando prescrevem vírgulas antes de pronomes relativos, de conjunções copulativas e disjuntivas, após nominativo absoluto, e para separar substantivos, adjetivos e verbos.

Já quando ressaltam o sentido imperfeito de uma oração, que só se completa com a oração que vem a seguir, após a vírgula, nesse caso os autores das ortografias estão vinculando ao uso da pontuação a dimensão textual, que privilegia a articulação das partes do texto, para garantir a coesão entre elas.

A dimensão fônica, descrita por Chacon (1998) como aquela que assinala pausas e delimita contornos entonacionais na escrita, não foi verificada nas normas de Argote ou de Feijó. Os autores dos compêndios ortográficos não estabelecem vínculo entre as funções da pontuação e as pausas da fala, confirmando resultados de estudos, como o de Rodrigues e Gonçalves (2020), que apontam para o abandono, particularmente no século XVIII, de critérios prosódicos como definidores do emprego da vírgula.

É nesse abandono da dimensão fônica que a pontuação do manuscrito parece alinhar-se às prescrições dos compêndios. O escriba não pontua com vírgulas unidades de escrita delimitadas por recursos gramaticais, como pronomes relativos e conjunções; mas também evita as pontuações prosódicas, mesmo quando o emprego da vírgula diante de pronomes e conjunções se justificaria pela evidente necessidade de pausa para respiração ou entonação, procedimento que facilitaria não só o ato de ler, como o entendimento do trecho.

Como exemplo, recortamos o excerto a seguir, linhas 6 a 10 da edição, composto por trinta palavras, em que o leitor acaba fazendo ao menos uma das necessárias pausas: ou de respiração - para não perder o fôlego,

Confluência. Rio de Janeiro: Liceu Literário Português, n. 61, p. 8-47, jul.-dez. 2021 
naturalmente delimitando os advérbios - e/ou de entonação - separando a oração subordinada adverbial consecutiva:

Havendo a Omnipotencia Divina avisado a estes Reinos em o dia primeiro de Novembro proximo pretérito com hũ terromoto taõ funesto que em cinco minutos de tempo arruinou os Templos, ...

Essa(s) pausa(s) favorece(m) a legibilidade ${ }^{22}$ do trecho. Afinal, a entonação propicia a organização do enunciado, para que o sentido do texto seja apreendido, ou, como explica Feijó, "para não perturbar o sentido do que está escripto". Mesmo assim, o escrivão não fixa vírgula em nenhum desses intervalos, deixando ao leitor a decisão e a conveniência da pausa, desconsiderando, tanto quanto Argote e Feijó, o critério prosódico como norma para pontuar o texto.

Continuando a análise das ausências de vírgulas no manuscrito setecentista, o escrivão ainda deixa de utilizá-las antes da conjunção aditiva "e", mas somente em quatro passagens do texto: nas linhas $15,19,46$ e 53. A falta de vírgula antes da conjunção "e", na linha 46, é a única que pode ser explicada como um possível "erro" do escrivão ou do copista. No caso das linhas 15, 19 e 53, coincidentemente, as aditivas "e" se posicionam no início da linha, situação que pode ter desfavorecido o emprego da vírgula, ou seja, a separação espacial entre a conjunção e a palavra que a precede, na passagem de uma linha para a outra, pode ter acabado por preencher a lacuna do sinal de pontuação. Também na linha 53, o clítico "e" está ligado à palavra "sobescrevi", impedindo assim a utilização da vírgula. Da mesma forma, podemos deduzir que na linha 43, onde se lê: Para o Juiz Vereadores, e Officiaes, a provável junção das palavras "juiz" e "vereadores", prática

22 O entendimento de que os sinais de pontuação garantem a legibilidade de um texto tem como base o domínio da atuação da dimensão enunciativa da linguagem (CHACON, 1998), na medida em que cabe aos sinais guiar o leitor a fim de recuperar o sentido pretendido pelo escrevente. (RODRIGUES e GONÇALVES, 2020).

Confluência. Rio de Janeiro: Liceu Literário Português, n. 61, p. 8-47, jul.-dez. 2021 
frequente no manuscrito, mas que não pode ser confirmada pela imagem facsimilar, eventualmente impediu a fixação da vírgula. Sendo assim, podemos inferir que nestes três casos não houve discordância do escriba em relação às regras dos compêndios, mas sim conjunturas de escrita manuscrita - como necessidade de mudança de linha e falta de fronteira entre palavras - que impediram a inserção das vírgulas.

\section{Considerações finais}

Os estudos linguísticos cujos resultados podem anunciar fatos relevantes sobre a história da língua portuguesa não podem ser prejudicados pela falta de rigor científico das edições. A crítica textual, cujo objetivo primordial é a restituição da forma genuína dos textos, tem contribuído para a recuperação e disponibilização de textos escritos, como patrimônio cultural, e como fontes confiáveis para os mais variados tipos de estudos, apesar das dificuldades encontradas principalmente em relação aos sinais de pontuação, suscetíveis a diferentes tipos de intervenções, intencionais ou não, na transmissão dos textos.

Com a análise dos elementos diplomáticos, codicológicos $\mathrm{e}$ paleográficos do manuscrito setecentista, foi possível anunciar suas propriedades filológicas, atribuindo-lhe, dessa forma, autenticidade e genuinidade, para então apresentar a edição fac-símile, um privilégio e um direito de consulta à imagem fotográfica do documento; e a edição semidiplomática, conservadora, fiel ao texto original, e ao mesmo tempo mais apreensível a leitores menos especializados.

Neste estudo, além do importante papel como doutrinas gramaticais representativas do século XVIII, os compêndios ortográficos desempenharam a relevante função de testemunhos diretos da escrita, colaborando para a autenticação do manuscrito como fonte documental segura para os estudos que dele se desenvolverem. 
Além disso, Argote e Madureira Feijó se destacam nas questões ortográficas nos anos setecentos ao propor o ensino de língua portuguesa como base para o ensino da língua latina, já que os autores acreditam que as regras do português e as do latim são, em sua maioria, equivalentes.

$\mathrm{O}$ estudo linguístico sobre o sistema de emprego das vírgulas no manuscrito setecentista, relacionado às ortografias de Argote e Feijó, coloca luz sobre uma das fases da pontuação na língua portuguesa, revelando práticas de escrita específicas do século XVIII. As regras para a pontuação apresentadas nas duas ortografias e o emprego das vírgulas no manuscrito são fundamentadas sob normatizações sintáticas e textuais - característica quase que exclusiva ${ }^{23}$ dessa centúria - já que, tanto nos séculos passados, como nos seguintes, nota-se com frequência a utilização, pelos gramáticos, do critério da necessidade de pausa para respiração no emprego da vírgula. Conforme Rodrigues e Gonçalves (2020, p. 238), no século XVIII, "a associação feita entre pausa na fala e vírgula na escrita já não parece ser mais suficiente para explicar o funcionamento da vírgula".

Por fim, a partir deste estudo ficam abertas interessantes possibilidades de novas e necessárias pesquisas, tanto de aprofundamento do tema proposto, como de investigações, com base em corpus mais consistente e homogêneo, de manuscritos, para se averiguar, por exemplo, possíveis mudanças no modo de emprego de vírgulas pelos escribas entre a primeira e a segunda metade do século XVIII.

23 Rodrigues e Gonçalves (2020), analisando gramáticas dos séculos XVII, XVIII e XIX, concluem que a função prosódica do uso da vírgula só não está presente nos autores do século XVIII. Chacon (1997) discute a percepção de alguns estudiosos - do século XX de que a pontuação demarca aspectos rítmicos da linguagem.

Confluência. Rio de Janeiro: Liceu Literário Português, n. 61, p. 8-47, jul.-dez. 2021 


\section{Referências}

ACKEL, A. Cartas pessoais de pacientes do Sanatório Pinel (1929

- 1944): um estudo filológico. 2019. 578 f. Dissertação (Mestrado em Filologia e Língua Portuguesa) - Faculdade de Filosofia, Letras e Ciências Humanas, Universidade de São Paulo, São Paulo, 2019. doi: 10.11606/D.8.2020.tde-20022020-165247. Disponível em: https://doi.org/10.11606/D.8.2020.tde-20022020-165247 . Acesso em: 15 jun 2020. ALMADA,M.Cultura escrita ematerialidade:possibilidades interdisciplinares de pesquisa. Pós: Belo Horizonte, v. 4, n. 8, p. 134 - 147. 2014.

ARGOTE, J. C. de. Regras da língua portuguesa, espelho da língua latina. Lisboa: Oficina da Musica, 1725. Disponível em: http://purl.pt/10. 356 p. Acesso em: 15 jun 2020.

BANZA, A. P.; GONÇALVES, M.F. Roteiro de história da língua portuguesa. Coleção Monografias: Évora: Cátedra UNESCO, 2018. ISBN 978-989-99442-6-8.

Disponível em: http://hdl.handle.net/10174/22196 . Acesso em: 15 jun 2020.

BELlOTTO, H.L. Como fazer análise diplomática e análise tipológica de documentos de arquivo. São Paulo: Arquivo do Estado/ Imprensa Oficial do Estado, 2002.

BLECUA, A. Manual de crítica textual. Madrid: Ed. Castalia, 1983 [reimpressão: 1990].

CAMBRAIA, C.N. Introdução à crítica textual. São Paulo: Martins Fontes, 2005.

CARDEIRA, E. O essencial sobre a história do português. Lisboa: Editorial Caminho S/A. 2006. ISBN 972-21-1778-5.

CHACON, L. Ritmo da escrita: uma organização do heterogêneo da linguagem. São Paulo: Martins Fontes, 1998. 
CHACON, L. A pontuação e a demarcação de aspectos rítmicos da linguagem. DELTA, São Paulo, v. 13, n. 1, p. 01-16, fev. 1997. Disponível em: https://doi.org/10.1590/S0102-44501997000100001. Acesso em: 15 de jun 2020.

COELHO, S.; FONTES, S. Ideias ortográficas de Madureira Feijó e de Soares Barbosa. Diacrítica, Braga, v. 28, n. 1, p. 457-477, 2014.

Disponível em: http://www.scielo.mec.pt/scielo.php?script=sci_ arttext\&pid=S0807-89672014000100018\&lng=pt\&nrm=iso. Acesso em: 15 de jun 2020.

COSTRINO, A. A transmissão da escrita sobre a retórica de Roma à Corte Carolíngia. Seminário Jornada de retórica. Plataforma Microsoft Teams. Realização Grupo ERA. 27 de mai 2020 - 12 às 13:30 h.

DAHLET, V. A pontuação e as culturas da escrita. Filologia e Linguística Portuguesa, [S. l.], n. 8, p. 287-314, 2006. DOI: 10.11606/issn.2176-9419. v0i8p287-314. Disponível em: https:/www.revistas.usp.br/flp/article/ view/59757 . Acesso em: 15 jun 2020.

DIAS, E. De uma página a outra - o reclame em livros manuscritos e impressos dos séculos XVI a XIX. São Paulo: Miró Editorial, 2018.

FEIJÓ, J. de M. M. Orthographia, ou arte de escrever; e pronunciar com acerto a língua portugueza. Lisboa: Na Oficina de Miguel Rodrigues, 1734. Disponível em: http://purl.pt/13. Acesso em: 15 jun 2020.

FELIPE, C.V.A.; CHAUVIN, J.P. Bastidores do terremoto de Lisboa, 265 anos depois Jornal da USP. São Paulo, 12/06/2020 Disponível em: https:// jornal.usp.br/?p=328861. Acesso em: 15 de jun 2020.

FERREIRA, P. T. Filologia como curadoria: o caso Pessoa. Filol. Linguíst. Port., São Paulo, v. 18, n. 2, p. 231-262, ago./dez. 2016. Disponível em: http://dx.doi.org/10.11606/issn.2176-9419.v18i2p231-262. Acesso em: 15 jun 2020. 
LARA, S.H. Os documentos textuais e as fontes do conhecimento histórico. Anos 90, Porto Alegre, v. 15, n. 28, p. 17-39, dez. 2008. Disponível em: https:// doi.org/10.22456/1983-201X.7953. Acesso em: 15 jun 2020.

LEITE, M. Q. A construção da norma linguística na gramática do século XVIII - Alfa, Revista de Linguística (São José do Rio Preto) ISSN 19815794 - vol. 55, n. 2, Dez 2011. Disponível em: https://doi.org/10.1590/S198157942011000200014 . Acesso em: 15 jun 2020.

LOSE, A. D. Edições de documentos históricos: a quem interessam? a quem se destinam?. Revista da ABRALIN, v. 16, n. 2, 26 abr 2017.

MAGALHÃES, J. Escrita e Municipalismo na transição do Brasil-colónia e na ideação do Brasil independente. Revista de História Regional v. 19 n. 2; 298311, 2014. Disponível em: https://doi.org/10.5212/Rev.Hist.Reg.v.19i2.0003. Acesso em: 15 jun 2020.

MARCOTULIO, L. L; LOPES, C. R. S; BASTOS, M. J. M. \& OLIVEIRA, T. L. O. (Orgs.) Filologia, história e língua: olhares sobre o português medieval. São Paulo: Parábola, 2018.

MENDES, M. G.; AMBROSILI, S. S. Crítica textual: volume 1. Rio de Janeiro: Fundação CECIERJ, 2015. 198. ISBN: 978-85-458-0002-6

NOGUEIRA, A.R.; BELlOTTO, H.L.; HUTTER, LM. Catálogo dos manuscritos Coleção Alberto Lamego. 2a . ed. São Paulo: IEB. EDUSP; 2002 PETRUCCI, A. Scrittura e libro nell'Italia altomedievale, il sesto secolo. Studi Medievali n. 10 vol. 1, 1970, p. 157-213.

RENOVATO, J. A reinvenção da vírgula - Jornal da USP, São Paulo, 28 ago 2019. Disponível em: jornal.usp.br/?p=268069. Acesso em: 15 jun 2020.

RODRIGUES, A. A. Funções da pontuação em construções relativas no português clássico: usos e normas. 2020, $144 \mathrm{f}$. Dissertação (mestrado) - Universidade Estadual Paulista (Unesp), Instituto de Biociências Letras e Ciências Exatas, São José do Rio Preto, 2020. 
RODRIGUES, A. A.; GONÇALVES, M. F. (2020). "Que cousa he virgula?": a mudança nas funções da vírgula em doutrinas gramaticais do século XVII ao XIX. LaborHistórico, 6(1), 225-245. doi: https://doi.org/10.24206/lh.v6i1.31955.

RUSSEL-WOOD, A J. R. Governantes e agentes. In: Bethencourt, Francisco \& Chaudhuri, Kirti (dir.). História da expansão portuguesa. Vol. $3 \mathrm{O}$ Brasil na balança do Império (1697-1808). Lisboa: Círculo de Leitores, 1998. Páginas 169-192.

SAID, E.W. Humanismo e crítica democrática. São Paulo: Companhia das Letras, 2007. ISBN 978-85-8086-545-5.

SANSIVIERO, M.T. C. et al. Inventário do sapateiro Damião Simões: um estudo físico químico do documento mais antigo do estado de São Paulo. Quim. Nova, Vol. XY, No. 00, 1-8, 200_ Disponível em: http://dx.doi. org/10.21577/0100-4042.20170426. Acesso em: 15 jun 2020.

SOUSA, M. D. de. Grammatica Portugueza. Coimbra: Na Real Imprensa da Universidade, 1804. Disponível em: http://purl.pt/17363. Acesso em: 15 jun 2020. SOUTO-MAIOR, F. F. C. Ortographia Portugueza ou regras para escrever certo, ordenadas para uso de quem se quizer applicar. Lisboa, por Francisco Luís Ameno, 1783.

SPINA, S. Normas gerais para os trabalhos de grau - um breviário para o estudante de pós-graduação. $4^{\mathrm{a}}$. edição revisada. São Paulo, Ateliê Editorial - 2003.

TELLES, C. M.; DA GAMA, A. R. Perspectivas da filologia textual. Revista do GELNE, v. 4, n. 2, p. 1-6, 29 fev. 2016.

VASCONCELOS, C. A; SANTIAGO-ALMEIDA, M. M. Contribuição da filologia e da crítica textual para o estudo de documentos manuscritos de Paranaguá. Signum: Estudos da Linguagem, [S.1.], v. 15, n. 1, p. 335-356, jan. 2012. ISSN 2237-4876. Disponível em: doi:http://dx.doi.org/10.5433/22374876.2012v15n1p335. 